\title{
Determining the Bench Size for Constitutional Adjudication
}

\author{
B Muthu Kumar *
}

\section{Abstract}

The Supreme Court of India acts as a Constitutional Court as well as the highest appellate court. The Constitution imposes mandatory minimum requirements for the strength of the Bench for constitutional adjudication. The apex Court has been criticized for constituting fewer number of Constitution benches, and for delaying the disposal of constitutional matters. Many Constitutional questions are being decided upon by Division benches or Constitutional benches, consisting of merely three members, due to prolific appeals in the Supreme Court. The researcher aims to analyze the question 'whether the size of the Bench matters for constitutional adjudication?' The article in the light of Constitutional provisions and the Supreme Court Rules, focuses on the impact of small and large benches, particularly in the highest Court of the land, where constitutional questions are decided upon. The Kesavananda Bharati case has been employed to examine the pros and cons of a large Bench, and the recent NJAC case is analyzed to bring out the problems of a smaller Bench, in overruling the decision of a larger Bench. The researcher therefore, attempts to answer the

* Assistant Professor, SRM School of Law, SRM University, Kattankulathur, Tamil Nadu, India; muthukumarml@gmail.com 
question whether a minimum required strength of the Bench in constitutional adjudication is required for the organic development of constitutional jurisprudence in our country.

Keywords: Article 145, Constitutional Bench, Constitution of India, NJAC, Supreme Court Rules.

\section{Introduction}

The most important function of the highest Court of the land is constitutional adjudication. As a Constitutional Court, it interprets the Constitution based on the prevailing circumstances, making it a living document. It also exercises its power of constitutional review of legislative and executive actions, when they violate any provision(s) of the Constitution. In addition to that, it also reviews the Constitutional amendment(s) and keeps the basic structure of the Constitution intact without being harmed by the legislature. There exist several distinctions between the adjudication of ordinary matters and Constitutional matters. It is important to understand the procedural requirements, besides the nuances of substantive processes in constitutional adjudication. Unlike the United States of America, the Supreme Court of India sits in fragmented Benches, for disposing cases of varied subject matters. There is no mandatory rule imposed on the Court, to sit as a unified Bench or in a specified strength, to decide the cases with the only exception as provided under Article 145(3). The Constitution permits the Supreme Court to lay down rules of procedure to hear appeals. ${ }^{1}$ It is a mandatory Constitutional requirement that when a question involves constitutional interpretation, the matter be decided by a Bench of not less than five judges in number. In the last decade, the Supreme Court has constituted lesser number of Constitutional benches, and has delayed the disposal of Constitutional matters. Many Constitutional questions are being decided upon by the Division Benches consisting of merely two or three members, due to the increasing number of appeals to the Supreme Court. The former Chief Justices of India have primarily been concerned with the disposal of regular appeal matters to clear

${ }^{1}$ THE CONSTITUTION OF INDIA, Art. 145(1). 
the backlog and therefore, have been reluctant to constitute a five or more judge Benches for a single case. Moreover, the Chief Justice of India is constrained to constitute two or three judge Benches to decide many important questions of law involving Constitutional interpretation, even though it is not a constitutionally mandated strength to decide Constitutional questions. $^{2}$ The question that arises is, whether the size of the Bench matters in constitutional adjudication or will a bigger bench provide a more efficient outcome in constitutional adjudication. This article focuses on the importance of Article 145(3) of the Constitution of India in adjudicating constitutional questions with a minimum number of five judges in the Bench.

\section{Procedure and Practice for constituting Constitutional Benches}

By virtue of Article 145 of the Constitution of India, the Supreme Court of India can regulate the procedure as regards to constitution and composition of the Benches for different matters, besides making formal rules and guidelines regulating practice and procedure in the Court. However, Article 145(3) casts a mandatory duty on the Supreme Court to constitute a Bench of minimum five judges, who are expected to sit for the purpose of deciding any case involving a substantial question of law, such as the interpretation of the Constitution. Further, Order VI of the Supreme Court Rules, 2013 provides for 'constitution of division courts and powers of a single judge'. ${ }^{3}$ Order VI Rule 2 states that 'where in the course of the hearing of any cause, appeal or other proceeding, the Bench (two judge) considers that the matter should be dealt with by a larger Bench, it shall refer the matter to the Chief Justice, who shall thereupon constitute such a Bench for the hearing of it.' The rule prohibits a vacation judge sitting singly during vacation, from entertaining applications for special leave to appeal in urgent cases, where interim relief is prayed for. However, when such a petition

2 Selvi v. State of Karnataka (2010) 7 SCC 263; Suresh Kumar Koushal v. NAZ Foundation \& Ors. (2014) 1 SCC 1; Nandini Sundar \& Ors v. State of Chattisgarh (2011)7 SCC 547.

${ }^{3}$ The Supreme Court Rules, 2013, O. VI. 
raises substantial question of law as to the interpretation of the Constitution, the Bench can entertain an application under Article 32 of the Constitution. In case it involves a substantial question of law as to the interpretation of the Constitution, then rule nisi alone should be issued. Similarly, Rule 1 and Rule 2 of Order XXXVIII, which deal with the applications for enforcement of fundamental rights (Article 32 of the Constitution) also, contain provisions to that effect. 4

\section{Whether Structure of the Court matters in constitutional adjudication}

The structure of legislative decision making, receives great attention, but legal commentators rarely consider how judicial structure might affect the quality of decision making. ${ }^{5}$ There is no definitive answer to the question of how large the highest Court of the land should be and the structure it should possess in handling constitutional cases. The structure of the highest Court in every country varies according to its suitability to the country's legal system. The Court may sit as a multi-panel or en banc, for cases pertaining to matters relating to the Constitution or otherwise. The functioning of multi-panel Courts in the United Kingdom (both House of Lords and now, the Supreme Court), Canada (the Supreme Court of Canada) are similar to that of India. Unlike India, certain Courts sit en banc, such as the Supreme Court of the United States of America, Constitutional Court of South Africa, and Supreme Federal Court of Brazil. Undoubtedly, the success of any Court in performing its tasks depends on the particulars of its institutional design in a large way and its overall image as a guardian institution, is fostered by its structure. ${ }^{6}$ The Court is widely perceived as a group of apolitical judicial experts who can

${ }^{4}$ The Supreme Court Rules, 2013, O. XXXVIII.

${ }^{5}$ Michael B. Abramowicz, En Banc Revisited, 100 Colum. L. Rev. 1600, 1601 (2000).

${ }^{6}$ F. Andrew Hessick and Samuel P. Jordan, Setting the size of the Supreme Court, 41 ARIZ. ST. L.J. 645, 647 (2009); Cass R. Sunstein and Adrian Vermeule, Interpretation and Institutions, 101 MICH. L. REV. 885, 920 (2003). 
be relied upon when other branches of the state fail. Its large size gives the Court an almost impersonal nature that helps foster a sense of expertise, even though its ability to take on many cases creates a more populist image at the same time. All of these characteristics are affected by the panel structure of the Court to varying extents. ${ }^{7}$

\section{Court with Large and Small Numbers}

There are varied arguments put forth by several authors concerning the advantages and disadvantages of having Courts with large and small numbers. A prominent argument against Courts with large numbers is that participation among the judges becomes difficult. Judge Posner explains: '....when the number of judges reaches the level, conventionally taken to nine, beyond which the deliberations of a Court come increasingly to resemble those of a legislature.' ${ }^{8}$ Thus, he believes that Courts will become a deliberative body like the legislature and will find it difficult to arrive at a solution within a time frame. While deciding constitutional matters, the Court shall efficiently and expediently handle it, rendering the decision to be transparent and reflecting the participation of all members with coherence and accuracy. An analysis of the same can be made by comparing the size of the Court and its impact based on the categories mentioned below:

A. Decisions that are efficient and expedite: Expanding the Court may expedite the decision of a case. But, more judges mean that more opinions may be worked on at once. This may lead to the increase in delays. Increased collegiality should yield greater efficiency because norms of productivity and group commitment enhance group performance. Active participation of individual judges may decrease as the bench gets larger, with members

7 Nick Robinson, Structure Matters: The Impact of Court Structure on the Indian and U.S. Supreme Courts, (Dec. 20, 2015), available at http:/ / ssrn.com/abstract=2061061.

8 RICHARD A. POSNER, THE FEDERAL COURTS: CHALLENGE AND REFORM 133 (Harvard University Press 1999); Supra note 7 at 1623. 
perceiving their contributions as not significant. ${ }^{9}$ Hence, minority views are expressed less and fewer dissenting opinions may be rendered. This effect is not necessarily connected to a loss of collegiality, but to diminished efficiency.

B. Transparency in decision making: Impartiality is an important aspect of transparency. While increasing the Court's size may help reduce the impact of prejudices, there is still a likelihood of partiality because each individual carries his or her own set of biases which may adversely affect decision making. Enlarging the bench may hinder deliberation, which results in each judge feeling less obliged to reconsider their own biases because of a belief that biases will have less impact given the larger Court. Expansion also presents the possibility of strengthening the effect of bias. ${ }^{10}$ Shared biases may become stronger due to group polarization, especially if no other judge holds a strong opposing view. ${ }^{11}$ Increasing the size of the Court will enhance judicial independence i.e. less direct interference and influence by Government and interest groups, or indirect influence by the press. However, excess independence may strip the judges of any accountability. ${ }^{12}$

C. Participation: Participation increases with diversity, representation and collegiality. Benches of larger sizes require additional resources. ${ }^{13}$ More importantly, size may have a direct effect on the Court's ability to satisfy the demands of the strong participation claim. Smaller groups tend to produce greater levels of participation. ${ }^{14} \mathrm{~A}$ Bench with large numbers has greater diversity

${ }^{9}$ A. Paul Hare, A study of Interaction and Consensus in Different Sized Groups, 17 AM. SOC. REV. 261, 267 (1952).

${ }^{10}$ Hessick \& Jordan, supra note 6 at 674.

${ }^{11} I d ., 675$.

12 John A. Ferejohn and Larry D. Kramer, Independent Judges, Dependent Judiciary: Institutionalizing Judicial Restraint, 77 N.Y.U. L. REV. 963, 981(2002); MACLAY, W., BOWLING, K. R., \& VEIT, H. E., THE DIARY OF WiLliam MAClAY AND OTHER NOTES ON SENATE DEBATES, (Johns Hopkins University Press, 1988)

${ }^{13}$ Hessick \& Jordan, supra note 6 at 688.

${ }^{14} I d$. 
and representation. Greater diversity on the bench may increase the public trust in the Court because it may convey a sense of inclusion to demographic groups that would otherwise be unrepresented on the Court, and this sense of inclusion may in turn generate greater public confidence in the court. Further, it increases the diversity of information and viewpoints held by the judges and will increase the total information on the bench, which will lead to more informed and better decisions. ${ }^{15}$ This indicates that a large Court is likely to produce greater diversity, and more diverse groups enjoy significant advantages in solving complex problems. ${ }^{16}$ However, a large Court does not guarantee the presence of more informational perspectives. If a Court is large and homogenous, then it has adverse effects in decisional output. For example, demographic diversity can restrict group deliberation by raising communication barriers and by triggering stereotyping. ${ }^{17}$ These barriers increase as group sizes expand, because larger groups have a greater tendency to break down into smaller self-segregated groups. ${ }^{18}$ Thus, even if a large number produces gain in both demographic and informational diversity, group performance may nonetheless suffer if the barriers created make it more difficult for the group to communicate and integrate informational inputs. ${ }^{19}$ One of the biggest obstacles in achieving the benefits of diversity is ineffectiveness in extracting and integrating competing perspectives from group members. The significance of that obstacle is sensitive to the group size because average member participation tends to decline and the number of non-participants

${ }^{15} I d .$, at 655.

16 Richard O. Lempert, Uncovering 'Nondiscernible' Differences: Empirical Research and the Jury-Size Cases, 73 MiCH. L. REV. 643, 685 (1975).

17 Harry T. Edwards, The effects of Collegiality on Judicial Decision Making, 151 U. PA. L. REV. 1639, 1669 (2003).

18 Robert M. Bray, Norbert L. Kerr \& Robert S. Atkin, Effects of Group Size, Problem Difficulty, and Sex on Group Performance and Member Reactions, 36 J. PERSONALITY \& SOC. PSYCHOL. 1224, 1233-34 (1978).

${ }_{19}$ Hessick and Jordan, supra note 6 at 682. 
tends to rise, as groups get larger. ${ }^{20}$ This is because larger groups present fewer opportunities to speak, with the more aggressive members tending to seize those opportunities. ${ }^{21}$ However, many of the obstacles that develop in larger groups may be counteracted through collegiality.22 Thus, collegial groups are better at promoting participation by all members, at avoiding stereotyping and communication breakdowns that can accompany demographic diversifications. ${ }^{23}$ Similarly, effective leaders can structure deliberation to encourage greater participation and foster commitment to shared values about the group's goals. However, it has to be noted, that both collegiality and leadership become more difficult to achieve as the size increases. ${ }^{24}$ Similarly size and collegiality may both affect the coherence of large group decisions. A larger group, particularly one that has a more diverse range of informational or value perspectives, is less likely to reach decisions that are agreed upon by the entire group, and the lack of consensus may have a negative impact on its coherence. Similarly, an increase in informational diversity may generate incoherence. The presence of multiple opinions in a given case may have adverse effects, if the fractured nature of the decision generates confusion about its precise contours. ${ }^{25}$ Although, in participation, large numbers have some disadvantages, it carries more weight both in precedent value and in the authority of the judgment, in the eyes of the public. ${ }^{26}$ The large numbers may also discipline decisions of the small judge panels by setting precedential consistency and certainty in the law.

\footnotetext{
${ }^{20}$ Bray, Kerr \& Atkin, supra note 18.

${ }^{21}$ BOBBY R. PATTON \& KIM GIFFIN, DECISION-MAKING GROUP INTERACTION 73 (Longman Higher Education, $2^{\text {nd }}$ ed., 1978).
}

${ }^{22}$ Edwards, supra note 17, 1641.

${ }^{23}$ Norbert L. Kerr \& R. Scott Tindale, Group Performance and Decision Making, 55 ANN. Rev. PsychOL. 623, 626 (2004).

${ }^{24}$ Edwards, supra note 17, 1675.

${ }^{25} \mathrm{Id}$., at 1651.

${ }^{26}$ Robinson, supra note 7 , at 120. 
D. Accuracy: In large numbers, the values associated with promoting high quality deliberation are collegiality, informational diversity, impartiality, participation, etc. are favoured largely because they promise to deliver a constructive exchange of opinions and perspectives that will generate superior and more accurate decisions. ${ }^{27}$ If a large number of judges consider a particular case, then the resulting majority decision will by definition be that of the majority of all judges. On the contrary, if just one judge is selected to resolve the case, the judge might not produce the same decision. ${ }^{28}$ There may be more straightforward relationships between size and accuracy. Accuracy might be promoted not through the productive interaction of views, but through their simple aggregation. ${ }^{29}$ Under an aggregation model, high quality deliberation or indeed, deliberation of any kind is unnecessary. ${ }^{30}$ Instead, accuracy is derived from pooling together the individually held views of group members. ${ }^{31}$ Perhaps, the most well-known aggregation claim is the Condorcet Jury Theorem (hereinafter ' $\mathrm{CJT}$ '). ${ }^{32}$ In general terms, CJT holds that if a decision has to be made between two choices, one correct and one incorrect and if all those who vote on the decision are more likely than not to make the correct choice, and if each votes independently of the others, then the probability that the majority of voters will make the correct choice increases. Kornhauser and Sagar assume initially that there are only two possible outcomes, that the judges who decide independently are likely to choose the correct outcome, and that each judge tends to choose the correct than the incorrect outcome. They argue that, under these conditions, adding judges

${ }^{27}$ Hessick and Jordan, supra note 6, at 693.

28 Abramowicz, supra note 5, at 1633.

${ }^{29}$ Lewis A Kornhauser and Lawrence G. Sager, Unpacking the Court, 96 YALE L. J. 82, 99-102 (1986).

30 Adrian Vermeule, Many-Minds Arguments in Legal Theory, 1 J. LEGAL ANALYSIS 1, 21 (2009).

31 Id., at 6.

32 Kornhauser and Sager, supra note 29, at 97-98 
to a decision increases the likelihood of an accurate decision. ${ }^{33}$ Hessick and Jordan discussed the problem governed by CJT by relying on Adrian Vermeule's work. ${ }^{34}$ Firstly, in its classic form, the Theorem applies to situations where there is an exogenously defined correct answer. Even if we assume that right answers are possible in law, exogenously defined correct answers are present only in some subset of cases, namely those, where one of the following conditions is met: (1) there is a factual component to the legal question; (2) there is a prescriptive or means-end judgment about which legal ruling will be conducive in achieving an agreedupon goal; (3) the legal question, although neither factual nor prescriptive, otherwise has a right answer somehow defined through philosophy, morality, or contemporary culture. No doubt, a substantial number of cases do not fall within these categories; they do not have 'right' answers. For them, the Theorem does not hold. Secondly, even for those cases where the condition of an exogenously defined correct answer is satisfied, there is a potential barrier associated with the requirement of independence. The cause for concern is not deliberation, but correlated bias. Random distribution of bias is a major force behind the Jury Theorem, but sometimes they are likely to err in the systematic rather than random ways and these errors will undercut group performance. ${ }^{35}$ All of this connects to size and the theorem in the following way. If background diversity is absent, then even a very large group may not satisfy the requirements of the Theorem, and it becomes more difficult to support a claim for increased size as a means of promoting accuracy. If background diversity is present, then the conditions for the Theorem may be met for some number of the

33 Benjamin R.D. Alarie, et al., Is Bigger Always Better? On Optimal Panel Size, with Evidence from the Supreme Court of Canada, SSRN, (May, 2011), available at http://papers.ssrn.com/sol3/ papers.cfm? abstract_id $=1152322$.

${ }^{34}$ Adrian Vermeule, Common Law Constitutionalism and the Limits of Reason, 107 COLUM. L. REV. 1482 (2007).

35 Id. , at 1500-01. 
Court's cases, and an expansion in size should increase the likelihood that the correct results are reached in those cases. ${ }^{36}$

The above vitiating elements of a large Bench can be well illustrated by the case of Kesavananda BharatiSripadagalavaru v. State of Kerala, ${ }^{37}$ (hereinafter Kesavananda case) which was the only case decided by the thirteen judge Bench of the Supreme Court of India. It was a landmark constitutional battle between the Parliament and the Supreme Court concerning the power of the Parliament to amend the Constitution. From day one, the Court witnessed lots of interesting outcomes both from the Bench and the Bar. Although, the judges were carefully selected by the CJI, it was equally divided for and against the Government. 38 The advocates made their arguments before the judges who were inclined to their view and not before those having conflicting views. Further, if any question posed by one of the judges is answered by another judge in the Bench either in favour or against the Government, it causes great embarrassment not only to the remaining judges sitting in the Bench, but also the advocates who are arguing the case. This lead to several heated debates and indecisive arguments in the Court. During the course of the arguments, Justice Beg became ill often, which detached him from the Bench and left him hospitalized when final arguments were advanced. Thus, the hospitalisation of Justice Beg hampered expediting the case and left the advocate with no other option but to submit the arguments in writing. Moreover, the retirement of Chief Justice Sikri, the very next day of the date of judgment, compelled the advocates to close their arguments early. In addition to that, some judges had no time to read all the eleven judgments as they were prepared under great constraints of time. Justice Chandrachud confessed that he just had time to scan through four draft judgments of his colleagues.

36 Richard A. Posner, Is the Ninth Circuit Too Large? A statistical Study of Judicial Qualtiy, 29 J. LEGAL STUD. 711, 717-718 (2000).

37 AIR 1973 SC 1461; (1973) 4 SCC 225.

38 T.R. Andhyarujina, Basic structure of the Constitution revisited, THE HINDU, (May 21, 2007), available at http:/ / www. thehindu. com / todayspaper/tp-opinion/basic-structure-of-the-constitutionrevisited/article1845048.ece. 
Although, the Bench was large with diverse views, the decision was affected by lack of participation by all members of the Bench and collegiality. There was not enough deliberation between the Justices to know the views of the brother judges and at times, Chief Justice Sikri called for a meeting but only with like-minded Judges. ${ }^{39}$ The act of the CJI showed a failure in encouraging greater participation of all members of the Bench in order to arrive at a precise and coherent decision. After the pronouncement of the eleven judgements in Court, the conclusion could not be reached due to lack of consensus. This compelled CJI Sikri to produce a paper titled the 'view of the majority' and obtain signatures of all 13 judges. One of the conclusions was that 'Parliament did not have the power to amend the basic structure or framework of the Constitution.' This was extracted from Justice H.R. Khanna's judgement. Nine judges signed the statement in the Court. Four others refused to sign it. A reading of the eleven judgments would show that this conclusion could not have been the view of the majority. The 'doctrine of basic structure' was born out of the views of one judge, Justice H.R. Khanna. The Chief Justice's action has been described by some as an act of statesmanship and others believe it was a manoeuvre to create a majority that did not exist. Thus, although it was a large Bench, the partial attitude of the Chief Justice allowed the controversial doctrine to be formulated.

However, there are certain disadvantages in small numbers as they cannot overrule the decision of larger benches. This is evident from the Supreme Court Advocates On-Record Association and others $v$. Union of India and others 40 (hereinafter NJAC case). In the said case, three Orders were passed, the first dealt with the recusal of one of the Judges, the second, a 'Reference Order' and the third, an Order on merits. Concerning the Order of reference, the Supreme Court held that the collegium system governed by the second and third judges cases, (Supreme Court Advocates-on Record Association v. Union of India 1993 and Re Special Reference 1 of 1998

39 T.R. ANDHYARUJINA, KESAVANANDA BHARATI CASE: THE UNTOLD STORY OF STRUGGLE FOR SUPREMACY BY SUPREME COURT AND PARLIAMENT 70 (Universal Law Publishing Co., 2011).

40 (2015) 6 SCC 408. 
respectively) would become a historical event of the past, as the new scheme contemplated under the impugned Constitution (99th Amendment) Act, along with the NJAC Act, would replace the earlier dispensation. ${ }^{41}$ In the above eventuality, the question of reexamination of the second and third judges' cases would be only academic. The court further held that however, if we accept the submissions of the petitioners, resulting in the revival of the earlier process, and simultaneously conclude in favour of the respondents, that the second and third Judges cases need a re-look, we would be obliged to refer this matter to a nine Judge Bench (or even, to a larger Bench), for reexamining the judgments rendered in the second and third Judges case.' 42 The majority judgement in this case favoured the petitioners but simultaneously found issues in the memorandum of procedure adopted by the collegiums, but not in the collegium itself found by the second Judges' case and confirmed in the third Judges' cases. Moreover, although the issue is a new one as held by the Court in this case, it heavily relied upon the judgements of the second and third judges' cases for their reasoning. This is because the Bench of lesser strength and judicial propriety has to follow the decision of a larger Bench. Further, the CJI can easily pick the smaller benches, which in turn can be tutored to the needs and circumstances. In this context, it is significant to mention the powers and functions of $\mathrm{CJI}$ in constituting Constitution Benches in India.

\section{Role of Chief Justice in Constituting Constitution Benches}

As per the normal practice, the Registrar (Judicial) prepares the roster for the Court's business and with the approval of the Chief Justice, the cause-lists are prepared showing matters assigned to various benches of judges. ${ }^{43}$ However, the Chief Justice can modify

\footnotetext{
${ }^{41}$ Advocates-on-Record Association v. Union of India, (1993) 4 SCC 441; Re: Special Reference No. 1 of 1998, (1998) 7 SCC 739.

42 Supreme Court Advocates On-Record Association \& Ors v. Union of India \& Ors, available at http://supremecourtofindia.nic.in/ FileServer/ 2015-10-16_1444997560.pdf.

43 VIJAY K. GUPTA, DECISION MAKING IN THE SUPREME COURT OF INDIA: A JURIMETRIC STUDY 97 (Kaveri Books, 1995).
} 
or change the cause list, if he so desires and can override the automated system of assigning cases and explicitly assign cases to his own or another's bench. It is clear that he plays a strong role not only in deciding which cases are heard by larger benches, but also cases heard by other judges. ${ }^{44}$ The bench assignments are not made randomly or by lottery, nor are they made by some rotation formula, which might restrict the Chief Justice's discretion. The period from 1950 to 1967, has provided evidence pointing to the conclusion that at least several of the Chief Justices of that period made bench assignments with a view towards achieving decisions and policy outputs they preferred. This was primarily done to maximize unanimity and minimize dissent. ${ }^{45}$ Further, he can speed up the hearing of cases or withhold a politically sensitive case, for years. He also creates the composition of benches that can effectively punish judges for outlier decisions. For example, he can place a non-conforming judge on a two judge bench or not include them on the larger and more powerful constitution benches of five or more judges. ${ }^{46}$ In the All India Law Teachers Conference, held on Dec. 27, 1979, at Varanasi, Hon'ble Justice Bhagwati, a member of the Court since 1973, made a different but pertinent point concerning the prerogative power of the Chief Justice in choosing the bench to decide a constitutional matter. ${ }^{47}$ Thus, the practices clearly show that bench assignments in the Supreme Court are exclusive prerogative of the Chief Justice and he enjoys considerable discretion in these matters. There is no express provision or procedure governing the bench assignments, but there are a number of factors which may be relevant in making bench assignments. They range from utilization of the judges' strength with a view to maximise the decisional output of the Court, effort to minimise overt dissent in the Court, where unanimity is a preferred value with the Chief Justice, and consideration like

${ }^{44}$ H.R. KHANNA, NEITHER ROSES NOR THORNS 77 (Eastern Book Co., 1987).

45 George Gadbois, Participation In Supreme Court Decision Making: From Kania To Vaidialingam, 1950-1967, 24 JILI (1982).

${ }^{46}$ Robinson, supra note 7 at 115.

47 Supra note at 45 . 
subject matter specialisation of judges or their interest in a particular area of the law to ideological preferences and their probable voting response in important controversies. ${ }^{48}$ Court packing is made easy by the Government either through the Chief Justice of the Court or directly through small Benches.

\section{Determination of the optimal size of 'Five Judge' Bench for Constitutional adjudication}

It is pertinent to analyse the deliberations of the members in the Constituent Assembly, in fixing not less than 'five judges' for constitutional adjudication as the 'best' ordering for setting the size of the Court. On June 6, 1949, Shri Alladi Krishnaswami Ayyar moved Art. 145(3) and clause (2)(a) of Art. 121. He did not make any comment over this provision because it speaks for itself, but spoke about the proviso, so as to save the time of the Court. ${ }^{49}$ Dr. Ambedkar accorded whole hearted support to Shri. Alladi Krishnaswami Ayyar, on the condition that the jurisdiction of the Supreme Court extends to criminal matters as well. ${ }^{50}$ Thus, there was no deliberation and difference of opinion among the members in fixing the minimum of five Judges to hear substantial question of law, as to the interpretation of the Constitution. Moreover, there is no view expressed that the Supreme Court has to sit en banc as like the Supreme Court of the United States. The founding fathers of the Constitution had consciously thought that the large number will pose great problems, resulting in the Court sitting with just eight judges including the Chief Justice. This precedent was also followed by the Supreme Court also en banc in the year 1950. However, due to accumulation of cases, it started to sit in benches of five, six and three. The Supreme Court Rules, 1950, provided

\footnotetext{
48 Robinson, supra note 7 at 98; Chaitanya Kalbag, A Battle Supreme, INDIA TODAY, (August 27, 2013) ,available at http://indiatoday.intoday.in/ story/more-hostile-public-confrontations-between-supreme-court-judgesfeared-in-the-future/1/392350.html

${ }^{49}$ Statement of Shri. Alladi Krishnaswami Ayyar, Constituent Assembly of India, Vol. VIII, 644-645 (June 6, 1949).

${ }^{50}$ Constituent Assembly of India, Vol. VIII, 650 (June 6, 1949).
} 
that at least three judges had to participate in every decision. But, with the widening jurisdiction, they could not continue the tempo of sitting in large number not even a three Judge Bench. The rule was amended very early to permit two Judge Benches.

\section{Conclusion}

Ascertaining the Bench size is easier said than done. It is difficult to determine what size would maximize any particular benefit in isolation. A group of three or four judges might for instance, maximize the benefits of deliberation, but a group of seven or nine might maximize accuracy. More importantly, setting a size to achieve one goal might undermine another. Conversely, reducing Court size to obtain effective participation, efficiency, and coherence, may impede diversity. Thus, how we set the size therefore depends on how we prioritize the goals of the Court. Undoubtedly, our Supreme Court has been vested with vast jurisdictions. It exercises original, appellate and advisory jurisdiction and the strength of the Bench becomes five or more, if any of the cases that arise in the above jurisdiction contains a substantial question of law as to the interpretation of the Constitution. In connection to it, the pros and cons of the large and small benches have been analyzed with the help of the Kesavananda case. ${ }^{51}$ Although, it is a celebrated judgment in the Constitutional history of India, the proceedings of the case were not sacrosanct. The partisan attitudes of certain Judges and even advocates, both inside and outside the Court, during the hearing of this case, shows the lack of independence of the Court. Besides the partisan attitude, the structure of the Court that is, a large Bench can cause unproductive outcomes because of lack of effective participation and collegiality, which directly affects the transparent nature of the Court. It is clear from this case that judges should not get personally attached with the issue at hand and should also refrain from mobilizing the opinion of other judges.

Although the framers of the Constitution had not deliberated more on Art. 145(3) of the Constitution, it is clear from the analysis that

${ }^{51}$ Keshavananada Bharti, AIR 1973 SC 1461. 
the five judge Bench arrived under Art. 145(3), as a minimum required strength for constitutional adjudication, is neither large nor small and is the optimal size. Moreover, the size of the Bench for constitutional adjudication has remained without any serious mishap, for almost sixty five years. Reassessing and perhaps changing the current size of the Constitution Bench by means of practice or by implied procedure, by reducing it to three for hearing important constitutional questions will create obstacles in promoting consistency and certainty in law. Thus, the compromise made in the application of Art. 145(3), for the purpose of clearing backlog of ordinary appeals will impair the organic development of Constitutional jurisprudence in India. 